Studies in African Linguistics

Volume 37, Number 1, 2008

\title{
A GENERATIVE ACCOUNT OF CONSONANT ALTERNATIONS IN BABA $1^{1}$
}

\author{
Nashipu Julius Pepandze \\ University of Yaounde 1
}

\begin{abstract}
This paper analyses and accounts for various patterns of alternations exhibited by consonants as they interact within morphemes in Baba 1. Most of the alternations manifested by the consonantal segments of this language are in accordance with general phonological principles. Nevertheless, there are some apparently complex alternations that may not be sufficiently accounted for using simple phonetic logic, and that exhibits some typological novelties, which may be of some theoretical interest to specialists in the field. Moreover, the underlying consonant system of this language constitutes a typological curiosity rarely documented in the world's languages. The contrast between voiced and voiceless consonants is highly restricted, appearing only with labio-dental, but never alveolar sounds.
\end{abstract}

\section{Introduction.}

This paper applies the generative theoretical framework in making a comprehensive analysis of alternations in consonant phonemes of morphemes and words in Baba 1, a Grassfields Bantu language of Cameroon spoken by about 15,000 people. This descriptive analysis will not only provide data on Baba 1, an understud-

I am quite grateful to David Odden for the patience he exercised in providing elaborate comments and suggestions, which led to the improvement made on the drafts of this paper. Anonymous reviewers of SAL also made useful observations that crucially contributed to the realisation of the final draft. 
ied language, it will also show that some general principles governing surface data in the language can be easily explained by using formalised mental rules.

1.1. Geographical location. The name Baba $1^{2}$ is used to refer to a village, people and language. This language, which Dieu et al (1983) variably refer to as Bapa or Bapakum, is spoken by the people of one of the thirteen settlements/villages in the Ndop plain, Ngoketunjia Division of the North-west province in the Republic of Cameroon. More precisely, it is located at $\left(6.06^{\prime} \mathrm{N}\right.$, $\left.10.49^{\prime} \mathrm{E}\right)$. The speakers call their language 'su papiax', translated as 'the speech of the Baba 1 people'. ${ }^{3}$ Grimes (1996) also refers to the language as Papia, Bapa, Bapakum; it has the Ethnologue code BBW.

1.2. Phonological processes. There are phonological alternations that arise as a result of morphological/syntactic processes. Alternations in Baba 1 include assimilation, strengthening processes, and deletion. The processes described will not only present general and language-specific phenomena, they will also reveal somewhat curious phonological manifestations peculiar to this language. These include the lateral becoming a corresponding stop when preceded by a nasal in word initial position but a trill becoming a retracted affricate in the same environment. Nasals are also seen to be deleted in the environment of voiceless fricatives. Moreover, the voiced velar fricative $[\gamma]$ and the velar stop $[\mathrm{g}]$ are allophones occurring in mutually exclusive environments. In initial position, $[\mathrm{g}]$ occurs exclusively before the high front vowels [i, ü], while the velar fricative precedes the remaining vowels. Finally, there is a highly restricted stop voicing rule, which voices the bilabial stop /p/ between two voiced sounds, but the other stops are unaffected in the same environment.

With these issues raised, we now present the phones of Baba 1 in (1).

\footnotetext{
2 This should be differentiated from Baba 2, which is a different village in Mezam division of the Republic of Cameroon, and whose language, which is not mutually intelligible with that of Baba 1, is classified under the Ngemba languages.

3 The translation is that of the author who is a native speaker of the language and presently a technical adviser to the language committee of the language.
} 
(1) Phones

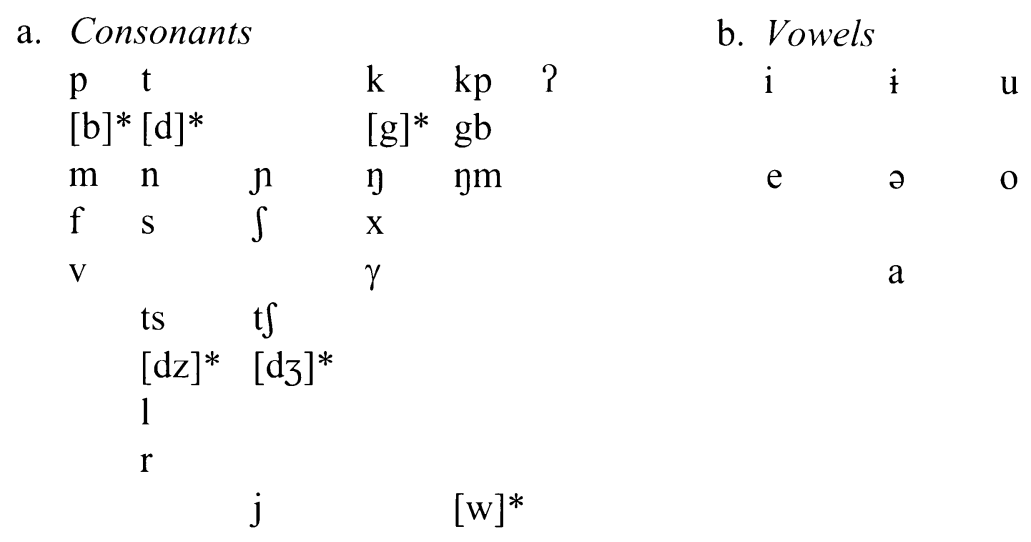

The sounds marked with asterisks are allophones as follows: $/ \mathrm{p} / \rightarrow[\mathrm{b}]$, $/ \mathrm{l} / \rightarrow[\mathrm{d}], / \gamma / \rightarrow[\mathrm{g}, \mathrm{w}], / \mathrm{r} / \rightarrow[\mathrm{dz}]$ and $/ \mathrm{j} / \rightarrow[\mathrm{d} 3]$. It is seen that apart from the voiced labio-velar stop, which contrasts with its voiceless counterpart as a separate phoneme, all of the other voiced stops and affricates in this language are allophones of other phonemes, as will be clearly illustrated in our analysis. Another peculiarity of this language is the presence of a contrast between voiced and voiceless labial fricative and the absence of such a contrast for their non-labial counterparts.

Before we begin with the analysis of the attested processes responsible for consonant alternations in Baba 1, it will be helpful to give some phonotactic facts about the language. With respect to the data of the language, the following remarks can be made. First, words in this language end with no consonant other than $[\mathrm{p}, \mathrm{m}, \mathrm{y}, \mathrm{P}, \mathrm{r}, \mathrm{x}]$. Second, there are no vowel-initial roots whatsoever, but single vowel segments can function as grammatical morphemes. The nasals of the language $[\mathrm{m}, \mathrm{n}, \mathrm{n}, \mathrm{n}]$ are not affected by a following vowel, but they are affected when preceding a consonant in initial position. Finally, the language does not have [z] or [3], but there are [dz] and [d3]. With these facts in mind about Baba 1, we now examine the attested assimilatory processes such as a consonant assimilating consonant feature and a consonant assimilating vowel feature as analysed below.

In this language, there are varied forms of consonant assimilation. A nasal takes on the place features of a following consonant, and a consonant may take the voice feature of surrounding sounds. The former describes exclusively the behaviour of nasals in word-initial position while the latter describes a bilabial stop between a nasal and a vowel. Rule (2) expresses this formally. 
(2) Nasal place of assimilation.

$$
[+ \text { nas }] \rightarrow\left[\begin{array}{l}
\alpha \text { ant } \\
\beta \text { cor }
\end{array}\right] / \#-\left[\begin{array}{l}
\alpha \text { ant } \\
\beta \text { cor }
\end{array}\right]
$$

Data in (3) and (4), wherein a noun class prefix and the first person singular subject marker respectively are used, illustrate the validity of our nasal assimilation rule. The language has certain nouns whose plural marker is a nasal prefixed to the noun. Similarly, the first person singular subject marker is usually a nasal prefixed as a clitic to the verb during sentence construction. These two items are used to illustrate nasal assimilation below.

(3) Assimilation of nasal in word-initial position.

Singular nouns

kù 'foot'

tónlá 'ear'

kóxtá 'knee'

t tìnlò 'buttock'
Plural

n-kù

n-tónló

n-kóxtó 'knees'

n-t t’inglà 'buttocks',

(4) 1st person subject pronoun. (asp = aspectual marker)

/Ǹ-tá mó wó/ [ì̀ má wó] 'I have kicked a stone'

I-kick asp stone

/Ǹ-tím mó k̀̀n/ [ǹtı́m má k̀̀n] 'I have carried a pot'

I -carry asp pot
/ Ǹ-kàn má/
[’̀̀kàn mó]
'I have cried'

I -cry asp

/̀̀-kpi má/

[’̀kpì má]

'I am absent'

I -absent asp

/Ǹ-gbàr má sú/

[ǹgbàr má sú] 'I have cut a fish'

I -cut asp fish

/Ǹ-mòm má/

[mìmòm mó]

'I have attempted'

I-attempt asp

${ }^{4}$ The nasal in this word does not assimilate the palatal place of articulation of the following consonant here because the sound $[\mathrm{t} f]$ is not considered a pure palatal in this language, but is better described as a prepalatal. 

/Ǹ-nè má/
[ǹnè mó]
'I have blocked'
I-block asp
/Ǹ-nà? má/
[j̀̀nà? mó]
'I have written'
I-write asp
/Ǹ-nóm má tít'/
[ỳyóm má tít]
'I have bent a tree'
I -bend asp tree

Since we do not have an argument strong enough to decide which among the attested nasals $(m, n, \eta, n)$ is underlying in this language, it is more convenient to assume an underlying nasal $/ \mathrm{N} /$ without any place of articulation feature. This nasal will only acquire a place feature on the surface from the following consonant.

Our rule in (2) applies to a nasal before a consonant in root initial position, as indicated by the word boundary, in order to account for the parallel examples in (5) below, where there is no assimilation.

(5) Non-assimilation of nasal within a word

$\begin{array}{lll}\text { mbùmtà 'weevil' } & \text { tónlá 'ear' } \\ \text { wùmtà 'umbrella' } & \text { fònlà } & \text { 'among' } \\ \text { lómlà 'delay' } & \text { síntá } & \text { 'name of a village' } \\ \text { vàmtà 'soft part of bamboo' } & \text { sónlà } & \text { 'speech' } \\ \text { yàmtà 'help' } & \text { kànlà 'friendship' } \\ \text { mòmtó 'to test' } & \text { fèntá 'to lock' } \\ \text { fántá 'to count' } & \text { séntá 'to break' }\end{array}$

The data above clearly illustrate that our proposed rule (2) applies exclusively in stem initial position in the presence of a preceding word boundary as indicated by data of $(3,4)$, and not elsewhere within the word.

The next issue to be addressed is a case where a sound takes on features from both preceding and following sounds. This is the curious case of the bilabial stop, which is voiced between a nasal and a vowel, whereas no other stop is voiced in this environment. This is formalized in (6) below.

(6) Bilabial stop becomes voiced between a nasal and a vowel.

$$
\left[\begin{array}{l}
+ \text { ant } \\
\text {-cont } \\
+ \text { lab } \\
\text {-voice }
\end{array}\right] \rightarrow[+ \text { voice }] /[+ \text { nas }] \ldots[+ \text { syll }]
$$


This rule is exemplified by the data in (7) below where we use a nasal that serves as marker for plural nouns in (a) and another nasal used as first person singular subject pronoun in (b).
a. pó
'hand'
m-bó
'hands'
pàm
'bag'
m-bàm
'bags'
pán
'tin'
m-bán
'tins'
b. /⿳亠丷⿵-póx mó/
I-struggle asp
[m̀bóx mó]
'I have struggled'
/Ǹ-pá má/
[m̀bá mó]
'I am mad'
I-mad asp
/Ǹ-púptá má/
I-spoiled asp
[m̀búptó má]
'I have spoiled'
/Ǹ-póm mə/
[m̀bóm mó]
'I have agreed' I-agree asp

Compare [ntá mó] in (4), where other stops do not change.

Another instance where a consonant takes on the feature of neighbouring sounds is when the voiceless bilabial stop and the velar fricative become voiced in this language. We simply give a single rule that takes care of these two contexts. The rule says: "a bilabial stop and a velar fricative are voiced between two vowels". This rule above describes a single unified process in Baba 1. Unfortunately the two sounds involved do not form a single natural class. For purpose of simplicity, we collapse the two rules to give the formalism in (8). 
(8) Voiceless bilabial stop and velar fricative become voiced

$$
\begin{aligned}
& {[\mathrm{p}, \mathrm{x}] \rightarrow[\mathrm{b}, \gamma] /[+ \text { syll }] \ldots[+ \text { syll }]} \\
& \left\{\begin{array}{l}
{\left[\begin{array}{l}
+ \text { cons } \\
+ \text { ant } \\
+ \text { lab } \\
- \text { voice }
\end{array}\right]} \\
{\left[\begin{array}{l}
+ \text { cons } \\
+ \text { back } \\
+ \text { cont } \\
\text {-voice }
\end{array}\right]}
\end{array}\right\} \rightarrow[\text { +voice }] /[+ \text { syll }]+\ldots[+ \text { syll }]
\end{aligned}
$$

Our rule in (8) will apply to give the surface forms in the data in (9) and (10), where 1 sg refers to first person singular possessive/direct object pronoun, and "+" indicates a morpheme boundary.

(9) Bilabial stop voicing
a. Noun citation form táp 'shoe'
Nouns + possessive /táp +á/ [tábá] 'my shoe' shoe-1sg
ggùp 'mat'

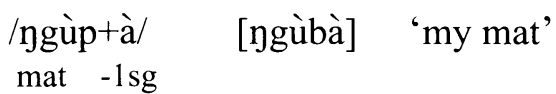
jkip 'left'
/nkìp+à/ [nkibà] 'my left'
left $-1 \mathrm{sg}$
sàp 'proverb'
/sàp +à/ [sàbà] 'my proverb'
proverb-1sg 
b. Verb citation form làp 'to beat'

sòp 'to stab'

píp 'to wait'

jǒp 'to sing'
Verb + direct object

$/$ lòp $+a ́ /$

beat-1sg

/sòp+á/

stab-1sg

/pip $+\mathrm{a} /$

wait-1sg

/jǒp+á/

sing-1sg

[làbá] [sòbá] 'Stab me!'

[píbá] 'Wait for me!'

[jòbá] 'Sing me'

(10) Velar fricative voicing

a. Noun citation form póx 'parcel'

láx 'calabash'

náx 'aubergine'

lóx 'poison'

b. Verb citation form yàx 'to grind'

mòx 'uproot'

nàx 'kill'

kjàx 'promise'
Nouns + possessive

/póx +á/ [póyá] 'my parcel' parcel-1sg

/láx +á/ [layá] 'my calabash' calabash-1sg

/náx +à/ [náyà] 'my aubergine' aubergine-1sg

/lóx +á/ [lóyá] 'my poison' poison-1sg

Verb + direct object

/yàx +á/ [yàyá]

grind-1sg

'Grind me!'

/mòx +á/ [mòyá] 'Uproot me!' uproot-1sg

/nàx+á/ [nàyá] 'Kill me!'

kill $-1 \mathrm{sg}$

/kjàx +á/ [kjàyá] 'Promise me!' promise-1sg 
The rule in (8) requires a restriction, such that it applies only to root-final position as indicated by the presence of a morpheme boundary. This is shown by the existence of forms in the language like Sàpún 'spoon', tépàrà 'table', páp̀̀ 'we/us', sápó 'finger', ’̀d’̀pà? 'tobacco' in which the bilabial stop is not voiced between vowels. However, there is one peculiar case where the bilabial stop is voiced in a context other than root-final. This is the case of the word váb' 'bitter leaf'. Nevertheless, this is the only word so far attested whereby our voicing rule seems to apply in root-internal position, thus posing as an exception.

One other case of a consonant alternation, resulting from its contiguity with a vowel, is the velar fricative which becomes an approximant when preceding a back rounded vowel, but a stop if the vowel is high and front. This can be expressed by a rule which states: "a velar fricative becomes a glide when preceding back rounded vowels, but a corresponding stop if the vowel is front and high." For the purpose of simplicity and ease of stating the restrictons involved, we represent this rule as (11a) and (11b) below:

(11) a. $\left[\begin{array}{l}+ \text { cons } \\ \text {-ant } \\ + \text { cont }\end{array}\right] \rightarrow[$-cont $] / \#-\left[\begin{array}{l}+ \text { syl } \\ - \text { back } \\ + \text { high }\end{array}\right]$
b. $\left[\begin{array}{l}+ \text { cons } \\ \text {-ant } \\ + \text { cont }\end{array}\right] \rightarrow[$-cons $] / \#-\left[\begin{array}{l}+ \text { syl } \\ + \text { back } \\ + \text { round }\end{array}\right]$

Our rules in (11) apply in discontinuous dependency, because the same underlying representation provides two different surface forms depending on the context. The same fricative becomes a stop if the following vowel is high and front (11a), but an approximant if and only if the following vowel is back and round (11b). These rules can only apply in stem initial position, as shown by the existence of pronominal forms in the language such as poyo 'we (excl.), puyi 'we (dual)'. The data in (12) exemplify the application of the rules in (11) where a velar fricative becomes a stop and an approximant respectively. 
(12) a. Velar fricative becomes a stop

\begin{tabular}{|c|c|c|}
\hline / jim/ & [gim] & 'to hold' \\
\hline $\mid \gamma_{1}^{\prime} /$ & [g'́1] & 'to mourn' \\
\hline 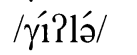 & [gípló] & 'to shape' \\
\hline /'̛́éêló/ & [gíé?ló] & 'kernel' \\
\hline /rián/ & [gián] & 'to frame' \\
\hline l'́rié/ & [g'́ée] & 'to be nice' \\
\hline / yưuáx/ & [gúáx] & 'to throw way" \\
\hline
\end{tabular}

b. Velar fricative becomes an approximant

\begin{tabular}{|c|c|c|}
\hline / үùmtà/ & [wùmtว̀] & 'umbrella' \\
\hline /үúá?/ & [wúá?] & 'type of vegetable' \\
\hline / үó/ & [wó] & 'stone' \\
\hline /үú/ & [wú] & 'death' \\
\hline / yóx/ & [wóx] & 'pride' \\
\hline /rúptá/ & [wúptó] & 'to measure' \\
\hline / үòptá/ & [wòptó] & 'to entangle' \\
\hline / qúkór/ & [wúkór] & 'adults' \\
\hline
\end{tabular}

c. Velar fricative unaltered before vowels other than $[\mathrm{i}, \mathrm{u}]$ and $[\mathrm{u}, \mathrm{o}]$ wù үì-mó nù 'you have done a thing'

2sg do-asp thing

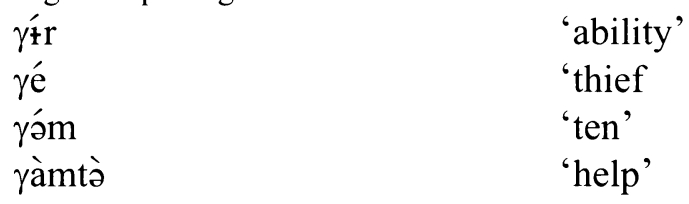

${ }^{5}$ The vowel / $/ \ddot{u} /$ in this word is not basic in the language. It is derived by a rule whereby a high back vowel is fronted when followed by a high front vowel and another vowel within the same syllable. The language does not allow a sequence of three vowels within the same syllable in words. If this happens, the second of the three vowels in such a sequence is deleted. In our example, /guiax/ is realized as [güax], meaning that after triggering the fronting of [u], [i] is deleted. It should be noted that vowel-fronting rule applies before consonant strengthening, so as to avoid the velar fricative becoming a glide. We will not belabour the rule where $/ \mathrm{u} /$ becomes [ü] since vowel alternation is not within the scope of this paper whose focus is on consonants. 
In this language, the sounds $[\gamma],[\mathrm{g}]$ and $[\mathrm{w}]$ are seen to exhibit a sort of complementarity in their distribution, occuring in mutually exclusive environments with respect to the vowels they precede in word initial position. The data in (12a-c) illustrate that $/ \gamma /$ can precede all other vowels in initial position except the high front and back rounded vowels. In addition, $\gamma$ and $w$ become [g] when preceded by a nasal as elaborated by data (14b). The data in (12a) reveal one of the curiosities of Baba 1. The behaviour of the velar fricative in (12b) can be accounted for using articulatory logic, i.e it assimilates the rounded quality of the following vowel. However, in (12a), $\gamma$ is already high, hence there is no apparently logical phonetic explanation for it becoming a stop before a high vowel.

The next type of alternation to be examined is consonant hardening/ strengthening.

\section{Consonant Hardening.}

There is a phonological process in this language whereby $/ 1, \gamma, \mathrm{r}, \mathrm{j} /$ become $[\mathrm{d}, \mathrm{g}$, $\mathrm{dz}, \mathrm{d}_{3}$ ] respectively after a nasal. To be more precise, we need a fortition rule which states: "continuants become corresponding stops and affricates when preceded by a nasal." This rule is formally presented in (13).

$$
[+ \text { cont }] \rightarrow[- \text { cont }] /[+ \text { nas }]
$$

The validity of the preceding rule is illustrated by the data in (14) below, where (asp) is the aspectual marker.

(14) a. Lateral becomes a stop.

$\begin{array}{lll}\begin{array}{l}\text { /Ǹ-líi mó/ } \\ \text { I-sleep asp }\end{array} & \text { [ñđíi mó] } & \text { 'I have slept' } \\ \begin{array}{l}\text { /N-lò? mó mù-à / } \\ \text { I-take asp child-my }\end{array} & \text { [ǹdò? mó mùà] } & \text { 'I have taken my child' } \\ \begin{array}{l}\text { /N-lúé mó/ } \\ \text { I-beg asp }\end{array} & \text { [ñdúé mó] } & \text { 'I have begged' } \\ \begin{array}{l}\text { /N-làà mó/ } \\ \text { I-pass asp }\end{array} & \text { [ǹdàà mó] } & \text { 'I have passed' }\end{array}$


b. Velar becomes a stop

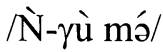

[ǹgù mó]

'I have fallen'

I-fall asp

/N-rúptá má/

[̀̀gúptá mó]

'I have measured'

I-measure asp

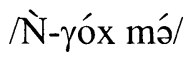

[ǹgóx má]

'I have become big'

I-big asp

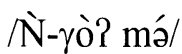

[ǹgó? má]

'I have swum'

I-swim asp

ハ̀-үè má nté/

[ǹgè má nté]

'I have gone to the market'

I-go asp market

/Ǹ-үì má jù/

I-do asp thing

/Ǹ-yàmtá má/

I-help asp

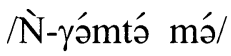

[ǹg̀̀ mó jú]

'I have done a thing'

I-welcome asp

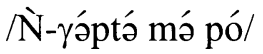

[ǹgàmtó mó]

'I have helped'

I -curve asp hand

[ǹgámtó má]

'I have welcomed'

[ỳgóptó mó pó] 'I have curved the hand'

c. A retracted trill becomes an affricate.

/Ǹ-rì má/

[ǹdzì mó]

'I have become old'

I-old asp

/Ǹ-rày mó ndzòx/ [ǹdzàn mó ndzòx] 'I have tapped wine'

I-tap asp wine

Ǹ-rùtá má/

[ǹdzùtó mó]

'I have shaken'

I-shake asp

/Ǹ-r̀̀?tó má/

[ǹdż̀t tó mó]

'I have ended'

I-end asp

ハ̀-ròp má/

[ǹdzòp mó]

'I have delayed'

I-delay asp 
d. A palatal glide becomes an affricate.
Ǹ-jòm mó ndáp/
[ǹdż̀m mó ndáp]
I-round asp house
'I have gone round
ハN-jé má yú/
[ǹdzé má yú] the house'
I-see asp thing
'I have seen something'
/Ǹ-jòy má màngóp/
[ǹdzòn má màngóp]
'I have chased a fowl'
I-chase asp fowl
/Ǹ-jàn má/
[ǹdzàn má]
'I have shouted'
I-shout asp
/Ǹ-jòp má nt ji/
[ǹdzòp má nt sì]
'I have sung a song'
I-sing asp song

The last part of our description deals with the deletion of nasal consonants.

\section{Consonant Deletion.}

Voiceless fricatives never appear after nasals in this language. A rule that explains this fact states: "a nasal is deleted when it precedes a voiceless fricative". This rule is concerned with $s, f, x$ and $\int$.

$$
\begin{aligned}
& / \mathbf{N} / \emptyset_{-}\left[\mathrm{s}, \mathrm{f}, \mathrm{x}, \int\right] \\
& {[+ \text { nas }] \rightarrow \varnothing /{ }_{-}\left[\begin{array}{l}
\text {-voice } \\
+ \text { cont }
\end{array}\right]}
\end{aligned}
$$

The rule in (15) explains the occurrence of the surface constructions obtained from the underlying forms of the data in (16) below. Here, (asp) as usual refers to aspectual marker. In deliberate slow speech, there may be a short schwa where the deleted nasal was (compare [à fú mó] 'it has grown', [(ว̀) fú mó] 'I have grown'. After the deletion of the syllabic nasal, its low tone remains and needs vocalic support to be phonetically realised. However, that vowel is not realized in ordinary speech: this process will need to be the subject of a separate study. 
(16) Deletion of nasal in pre-fricative position.

Underlying forms

/N-fú mó ygbí /

I-return asp farm

/Ǹ-sé má láx/

I-break asp calabash

ハ̀̀-sù? mó ndzó/

I-wash asp dresses

/Ǹ-Súr mó nì̀x/

I-cut asp cow

ハ̀-xìò má ymè/

I-laugh asp person
Surface forms

[à fú mó ngbí]

[ò sé mó láx]

[ว̀ sù? mó ndzó]

[à Síi mó nìx]

[à x’̀o mó ymè]

ハ̀̀-xì?ló mó màmvía

I-frighten asp dog
Gloss

'I have returned from the farm.'

'I have broken

a calabash.'

'I have washed dresses.'

'I have slaughtered a cow.'

'I have laughed at

a person.'

It is interesting here to use parallel examples to show that the voiced counterparts of these fricatives in similar environment do not delete as illustrated in (17).

(17) Non-deletion of nasal in the context of $\mathrm{N}+$ voiced fricative.

ハ̀̀-vám mó jú/ [mivám mó ní]

'I have searched for a cutlass.'

I-search asp cutlass

/Ǹ-vù mó ndáp/ [mivù mó ndáp] 'I have constructed a house.'

I-construct asp house

/Ǹ-үè má/

[ǹgè mó]

'I have gone.'

I-go asp

Ǹ̀-yáxló má/

[ỳgáxló má]

'I have choked'

I -choke asp

In the last two constructions in (17) above, rule (13) has applied to harden the velar fricative. 


\section{Conclusion.}

Our description of alternations in Baba 1 has revealed that, although most of the changes undergone by the various consonants take place in the vicinity of a nasal in stem initial position, nasals nevertheless tolerate somewhat curious patterning with other consonants within the word. Similarly, certain language specific tendencies have been revealed. A case in point is the hardening of velar fricative before high front vowel and the deletion of nasals preceding voiceless fricatives, which are not too common phenomena documented in Bantu languages.

Moreover, in documenting these alternations, the paper has provided a considerable amount of data which can serve as a source of reference for the investigations into some of the unexplained issues raised in the paper.

\section{References}

Grimes, Barbara F. (1996). Ethnologue - Languages of the World. Summer Institute of Linguistics, $13^{\text {th }}$ edition.

Dieu, Michel \& Patrick Renaud, P. 1983. Atlas Linguistique du Cameroun: Inventaire Préliminaire. Yaoundé Cameroun, DGRST (CERDETOLA).

Department of African Languages and Linguistics

[received April 8, 2004

University of Yaounde 1-Cameroon jnashipu@yahoo.com

accepted August 27, 2008] 
